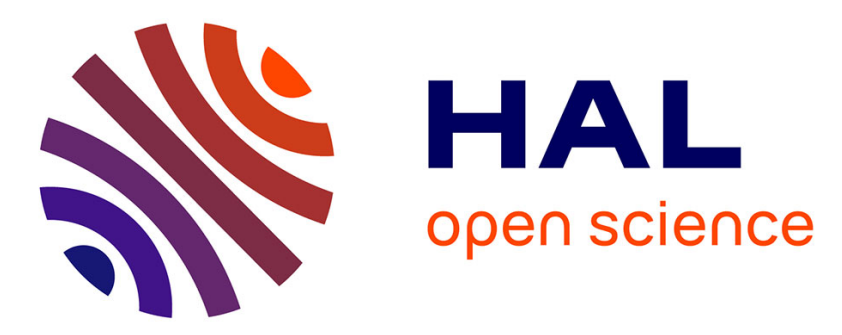

\title{
Quantification of free total plasma DNA and minimal residual disease detection in the plasma of children with acute lymphoblastic leukemia
}

Arne Kristian Schwarz, Martin Stanulla, Gunnar Cario, Thomas Flohr, Rosemary Sutton, Anja Möricke, Philippe Anker, Maurice Stroun, Karl Welte, Claus R. Bartram, et al.

\section{To cite this version:}

Arne Kristian Schwarz, Martin Stanulla, Gunnar Cario, Thomas Flohr, Rosemary Sutton, et al.. Quantification of free total plasma DNA and minimal residual disease detection in the plasma of children with acute lymphoblastic leukemia. Annals of Hematology, 2009, 88 (9), pp.897-905. 10.1007/s00277-009-0698-6 . hal-00535029

\author{
HAL Id: hal-00535029 \\ https://hal.science/hal-00535029
}

Submitted on 11 Nov 2010

HAL is a multi-disciplinary open access archive for the deposit and dissemination of scientific research documents, whether they are published or not. The documents may come from teaching and research institutions in France or abroad, or from public or private research centers.
L'archive ouverte pluridisciplinaire HAL, est destinée au dépôt et à la diffusion de documents scientifiques de niveau recherche, publiés ou non, émanant des établissements d'enseignement et de recherche français ou étrangers, des laboratoires publics ou privés. 


\title{
Quantification of free total plasma DNA and minimal residual disease detection in the plasma of children with acute lymphoblastic leukemia
}

\author{
Arne Kristian Schwarz • Martin Stanulla • \\ Gunnar Cario • Thomas Flohr • Rosemary Sutton • \\ Anja Möricke • Philippe Anker • Maurice Stroun • \\ Karl Welte • Claus R. Bartram • Martin Schrappe • \\ André Schrauder
}

Received: 10 July 2008 / Accepted: 9 January 2009 / Published online: 23 January 2009

(C) Springer-Verlag 2009

\begin{abstract}
The analysis of total plasma DNA and the monitoring of leukemic clone-specific immunoglobulin and/or T-cell receptor gene rearrangements for the evaluation of minimal residual disease (MRD) in the plasma may be useful tools for prognostic purposes or for early detection of subclinical disease recurrence in children with acute lymphoblastic leukemia (ALL). The aim of this paper is to establish reference ranges for total plasma DNA concentrations and to test the feasibility of MRD measure-
\end{abstract}

This work was supported by the Deutsche Krebshilfe (Bonn, Germany) and the Leukemia Research Foundation (Chicago, IL, USA).

\footnotetext{
A. K. Schwarz $\cdot$ K. Welte

Department of Pediatric Hematology and Oncology,

Hannover Medical School,

Hanover, Germany

M. Stanulla $\cdot$ G. Cario $\cdot$ T. Flohr $\cdot$ A. Möricke $\cdot$ M. Schrappe

A. Schrauder $(\square)$

Department of Pediatrics, University Hospital Schleswig-Holstein,

Campus Kiel, Schwanenweg 20,

24105 Kiel, Germany

e-mail: a.schrauder@pediatrics.uni-kiel.de

R. Sutton

Children's Cancer Institute Australia,

Randwick, Australia

P. Anker $\cdot$ M. Stroun

Department of Plant Biochemistry and Physiology,

University of Geneva,

Geneva, Switzerland

C. R. Bartram

Institute of Human Genetics, University of Heidelberg,

Heidelberg, Germany
}

ments employing plasma DNA from children with ALL by using real-time quantitative (RQ)-PCR. Despite wide interindividual variation, the median concentrations of total plasma DNA for 12 healthy donors $(57 \mathrm{ng} / \mathrm{ml}), 21$ children with ALL after day 4 of treatment initiation $(62 \mathrm{ng} / \mathrm{ml})$ and 13 children with other malignancies $(76 \mathrm{ng} / \mathrm{ml})$ were similar. However, ALL patients had significantly higher concentrations at diagnosis $(277 \mathrm{ng} / \mathrm{ml})$ and on treatment day $3(248 \mathrm{ng} / \mathrm{ml})$ before returning to normal afterwards. Early plasma DNA MRD kinetics could be established for 15 ALL patients and showed good concordance with bone marrow MRD. Plasma DNA was higher in children with ALL at diagnosis but returned to normal within the first four treatment days. Despite low concentrations of DNA, it is feasible to measure MRD kinetics in plasma DNA during ALL induction therapy by adapted real-time PCR methodologies.

Keywords Acute lymphoblastic leukemia - Childhood . Minimal residual disease $\cdot \operatorname{Ig} / \mathrm{TCR}$ gene rearrangements . Plasma DNA

\section{Introduction}

Over the past 40 years, a number of studies have been published on the presence of free circulating nucleic acids in the blood plasma of humans. In this context, various malignancies have been associated with increased concentrations of free plasma DNA as compared to levels in healthy controls [1-3]. It has therefore been proposed that analyses of free plasma DNA could be a useful tool for 
prognosis or the early diagnosis to detect subclinical disease recurrence [4]. Since the introduction of PCR-based techniques in the late $1980 \mathrm{~s}$, a large number of tumorspecific alterations have been identified in free plasma DNA, such as K-ras mutations in patients with colorectal cancer [5], microsatellite alterations in patients with smallcell lung cancer [6], head and neck cancer [7], clear cell renal carcinoma [8] and melanoma [9], and finally aberrant promotor hypermethylation of tumor suppressor genes in patients with non-small-cell lung cancer [10], liver [11], and breast cancer [12]. Whereas the majority of these studies examined patients with solid tumors, it has also been suggested that free plasma DNA can be used for the detection of molecular abnormalities in hematological malignancies [13-15].

In acute lymphoblastic leukemia (ALL), the detection of minimal residual disease (MRD) using leukemic clonespecific immunoglobulin (Ig) and T-cell receptor (TCR) rearrangements as PCR targets provides important prognostic information on the in vivo effectiveness of early treatment [16-20]. Up to now, most large-scale MRD studies have been performed using bone marrow (BM) aspirates. Due to a lack of study, there is no information available on both the DNA concentration in the plasma of healthy children as well as the abundance of tumorspecific plasma DNA in children with hematological malignancies (e.g., ALL) or solid tumors. As such information could potentially provide a basis for the use of plasma DNA for MRD measurements in children with malignant neoplastic diseases, we aimed to establish reference ranges for the total concentration of free plasma DNA in children and to evaluate the feasibility of MRD measurement in the early course of childhood ALL by means of plasma DNA.

\section{Materials and methods}

\section{Patients}

Peripheral blood (PB) samples were obtained from 21 children with ALL at diagnosis and during the 12-week induction therapy, 13 children with other malignancies during therapy and 12 healthy children (Table 1). All samples were collected under protocols approved by the Institutional Review Board of the Medizinische Hochschule Hannover and after informed consent was given by the parents and/or patients.

\section{Sample processing}

As previous studies have demonstrated that EDTA prevents DNA degradation [14] and that coagulation-associated factors may influence the concentration of cell-free DNA in serum [21], we systematically used EDTA tubes to collect $\mathrm{PB}$ samples and exclusively worked with $\mathrm{PB}$ plasma.

To determine the possible influence of the storage period on the total concentration of DNA being measured in the plasma, we performed pilot experiments in which the plasma was separated from blood cells at $6,12,24,36$, and $48 \mathrm{~h}$ after collection. The plasma DNA concentrations were stable for up to $24 \mathrm{~h}$ of storage, but increased after longer time intervals. These results were in accordance with previous experiments performed by Anker et al. [22]. As a consequence, all plasma samples analyzed in the present study were separated from PB within $24 \mathrm{~h}$ by centrifugation $(2 \times 10 \mathrm{~min}$ at $3,000 \times g)$. Leukocytes were isolated by Ficoll-Paque $^{\mathrm{TM}}$ Plus density centrifugation (Amersham Biosciences, Piscataway, NJ). The obtained plasma samples

Table 1 Characteristics of individuals included in plasma DNA analysis

\begin{tabular}{|c|c|c|c|c|c|}
\hline & \multirow[t]{2}{*}{ No. of patients } & \multirow[t]{2}{*}{ No. of samples } & \multicolumn{2}{|c|}{ Gender } & \multirow[t]{2}{*}{ Age, year (range) } \\
\hline & & & Male & Female & \\
\hline ALL & 21 & 150 & 8 & 13 & $5(2-16)$ \\
\hline \multicolumn{6}{|l|}{ Other malignancies } \\
\hline AML & 2 & 2 & 1 & 1 & 13 \\
\hline Anaplastic astrocytoma 1 & 1 & 1 & & 1 & 11 \\
\hline Hepatoblastoma & 1 & 2 & 1 & & 7 \\
\hline Medulloblastoma & 1 & 1 & 1 & & 8 \\
\hline Nephroblastoma & 3 & 5 & 3 & & $9(6-12)$ \\
\hline Neuroblastoma & 1 & 1 & 1 & & 11 \\
\hline NHL & 3 & 4 & 1 & 1 & $9(6-12)$ \\
\hline Rhabdomyosarcoma & 1 & 3 & 1 & & 8 \\
\hline Total & 13 & 20 & 10 & 3 & $9(6-13)$ \\
\hline Healthy controls & 12 & 12 & 10 & 2 & $8.5(1-17)$ \\
\hline
\end{tabular}

$A M L$ Acute myelogenous leukemia, $N H L$ non-Hodgkin lymphoma 
were then further processed using the QIAamp ${ }^{\circledR}$ UltraSens Virus Kit to isolate plasma DNA. For the extraction of cellular DNA (e.g., from leukocytes), we employed the QIAamp ${ }^{\circledR}$ Blood Midi Kit (Qiagen, Hilden, Germany).

\section{$\beta$-Actin real-time quantitative PCR (RQ-PCR)}

To determine the total amount of plasma DNA, we established a $\beta$-actin (housekeeping gene) RQ-PCR with primers $\beta$-Actin $F$ (TCACCCACACTGTGCCCATC TACGA) and $\beta$-Actin R (CAGCGGAACCGCTCATTGC CAATGG), using the LightCycler ${ }^{\mathrm{TM}}$ system (Roche Diagnostics, Mannheim, Germany). Each PCR was conducted using a buffy coat DNA dilution series (tenfold steps; range, $15 \mathrm{ng} / \mu \mathrm{l}$ to $1.5 \mathrm{pg} / \mu \mathrm{l})$, a standard DNA as external control (150 pg/ $\mu \mathrm{l}$; LightCycler ${ }^{\mathrm{TM}}$ Control Kit DNA), two negative controls $\left(\mathrm{H}_{2} \mathrm{O}\right)$, and the plasma DNA of patients (all in duplicate). All reactions were performed with LightCycler ${ }^{\mathrm{TM}}$ FastStart DNA Master SYBR Green I (Roche Diagnostics, Mannheim, Germany). The running protocol was programmed on the LightCycler ${ }^{\mathrm{TM}}$ software, version 3.5. The first step was an initial denaturation where the reaction was incubated for $10 \mathrm{~min}$ at $95^{\circ} \mathrm{C}$. In the second step, DNA was amplified for 50 cycles of $1 \mathrm{~s}$ at $95^{\circ} \mathrm{C}, 10 \mathrm{~s}$ at $68^{\circ} \mathrm{C}-60^{\circ} \mathrm{C}$, and $10 \mathrm{~s}$ at $72^{\circ} \mathrm{C}$. Melting curve analyses were performed subsequently to verify the amplification specificity. A final cycle consisted of $1 \mathrm{~s}$ at $95^{\circ} \mathrm{C}, 10 \mathrm{~s}$ at $64^{\circ} \mathrm{C}$, and $1 \mathrm{~s}$ at $95^{\circ} \mathrm{C}$, followed by one cycle of $15 \mathrm{~s}$ at $40^{\circ} \mathrm{C}$.

\section{Allele-specific RQ-PCR for leukemic MRD analysis}

Identification and sequencing of patient-specific gene rearrangements was carried out as part of routine MRD analysis for the clinical trial ALL-Berlin-FrankfurtMünster 2000 (BFM 2000), at the Institute of Human Genetics, University of Heidelberg, Germany. Briefly, genomic DNA from ALL samples at diagnosis was screened by PCR amplification using the BIOMED-1 primer sets for immunoglobulin kappa, IGK, deleting element (Kde) gene rearrangements (V-Kde, intron-Kde), complete and incomplete TCR delta, TCRD (V-(D)-J1, D2J1, V2-D3, D2-D3), and TCR gamma, TCRG (V-J1.3/2.3, V-J1.1/2.1) rearrangements. Complete and incomplete $I G H$ rearrangements $\left(\mathrm{V}_{\mathrm{H}^{-}}\left(\mathrm{D}_{\mathrm{H}}\right)-\mathrm{J}_{\mathrm{H}}, \mathrm{D}_{\mathrm{H}^{-}} \mathrm{J}_{\mathrm{H}}\right)$ were identified using five $\mathrm{V}_{\mathrm{H}}$ and six $\mathrm{D}_{\mathrm{H}}$ family primers in combination with one $\mathrm{J}_{\mathrm{H}}$ consensus primer. As an extra PCR target for T-ALL patients, primer sets to detect the SIL-TAL1/2 deletion were included in the PCR screening protocol utilizing breakpoint-spanning SIL gene forward and TAL gene reverse oligonucleotides. If no DNA rearrangements were identified for IGH,IGK-Kde, TCRG, TCRD, and SIL-TAL deletion, in a subset of patients alternative targets were added such as complete and incomplete TCRB (V-(D)-J, $\mathrm{D}-\mathrm{J}), I G K(\mathrm{~V}-\mathrm{J})$, and $I G L(\mathrm{~V}-\mathrm{J})$ using the respective BIOMED-2 multiplex PCR primer sets. PCR products obtained from Ig and TCR gene rearrangements were further examined by heteroduplex or gene scanning analysis to discriminate between amplifications derived from monoclonal or polyclonal lymphoid cell populations. Biclonal or biallelic PCR products were separated either by cutting out amplicons from the polyacrylamide gel or by DNA cloning. Junctional regions of monoclonal PCR products were sequenced. Thereafter, patient-specific junctional region sequences of potential MRD PCR targets were identified using the IMGT (http://www.imgt.cines.fr), Vbase (http://www.vbase.mrc-cpe.cam.ac.uk), or IgBlast (www.ncbi.nlm.nih.gov/igblast/) databases and commonly distributed hardcopy sequences. At least one allelespecific oligonucleotide (ASO) primer was designed complementary to the junctional region sequence of each target either manually or using the Primer Express software (Applied Biosystems, Darmstadt, Germany).

Since the concentration of DNA in plasma was very low compared to the $500 \mathrm{ng}$ used in all routine bone marrow analyses, all markers were re-evaluated for their effectiveness in detecting MRD at the low levels of DNA found in plasma. Each patient's BM mononuclear cell DNA from day $0(150 \mathrm{pg} / \mu \mathrm{l}$; diluted with AE buffer (Qiagen, Hilden, Germany) was used to prepare a tenfold dilution series in DNA isolated from the buffy coat fraction from normal individuals. The dilution series was used to test all the RQ-PCR assays for markers available for each patient with hybridization temperatures adapted according to the primerannealing temperatures. The assays used LightCyclerTM FastStart DNA Master SYBR Green I on LightCycler ${ }^{\mathrm{TM}}$ equipment and all included two negative controls $\left(\mathrm{H}_{2} \mathrm{O}\right)$ and three buffy coat samples for defining the non-specific background signals.

We established criteria to distinguish between an informative and a non-informative marker, with the melting curve analysis being the determining factor. A marker that showed a clear distinction between buffy coat and negative control on the one hand and the patient-specific DNA (BM, day 0 ) on the other hand, was assessed as informative (Fig. 1).

MRD assessment in plasma and peripheral leukocytes

MRD detection in PB leukocytes was conducted as published by others [23-26]. Briefly, MRD PCR targets were tested for specificity and sensitivity to enable on-time monitoring of remission samples. RQ-PCR analysis was performed either by using single PCR amplification with sequence-specific TaqMan hydrolysis probes or by a two-round nested RQ-PCR including SYBR Green I 
Fig. 1 Allele-specific RQ-PCR for testing patients markers. a Detection of amplification products by SYBR Green. $V 0-V 3$ dilution series with day 0 BM, $\mathrm{H}_{2} \mathrm{O}$ : negative control. $b c$ buffy coat to define non-specific background signals (slope $-2.47 ; r=-0.98)$. b Melting curve analysis. Showing a specific melting point for $\mathrm{V} 0$, $\mathrm{V} 1$, and $\mathrm{V} 2$ at $88^{\circ} \mathrm{C}$, identifying the marker as informative. The amplification curve of $\mathrm{V} 3$ which arises between V1 and V2 (Figure 1A) should be disregarded for further analysis of this specific MRD-target as it is an unspecific amplification, shown by the melting curve analysis

(Figure 1B)

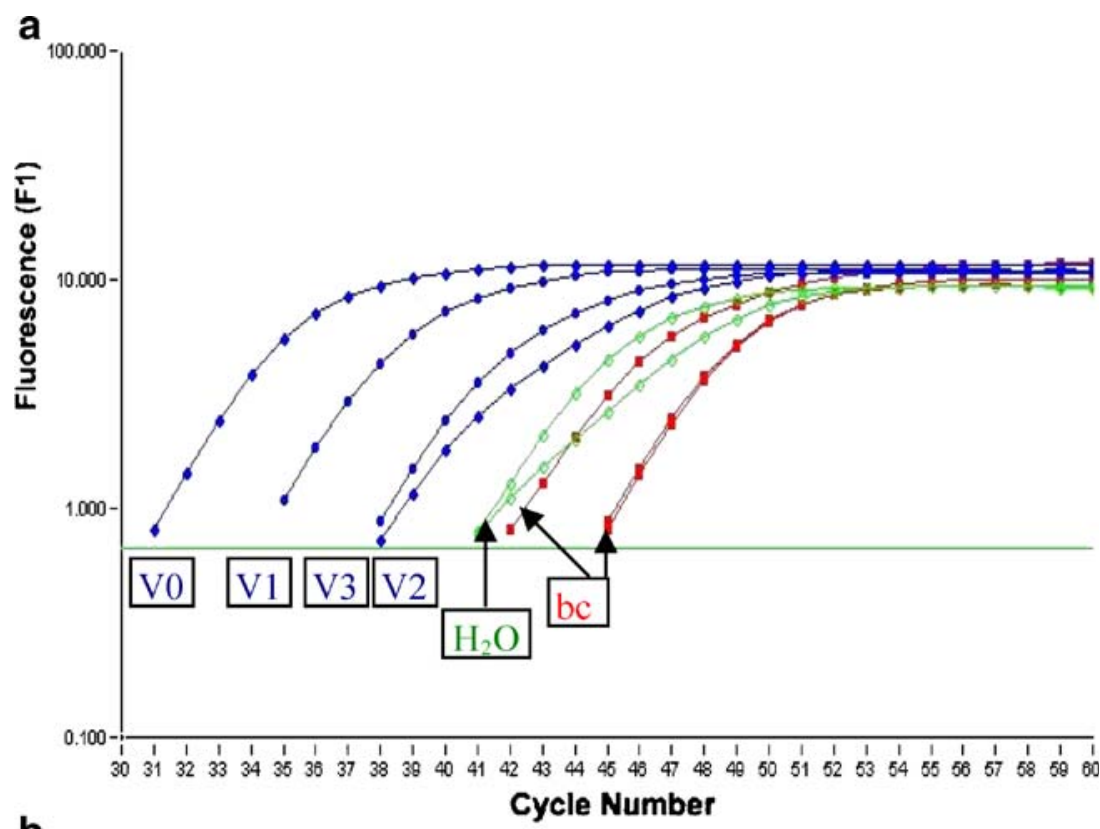

b

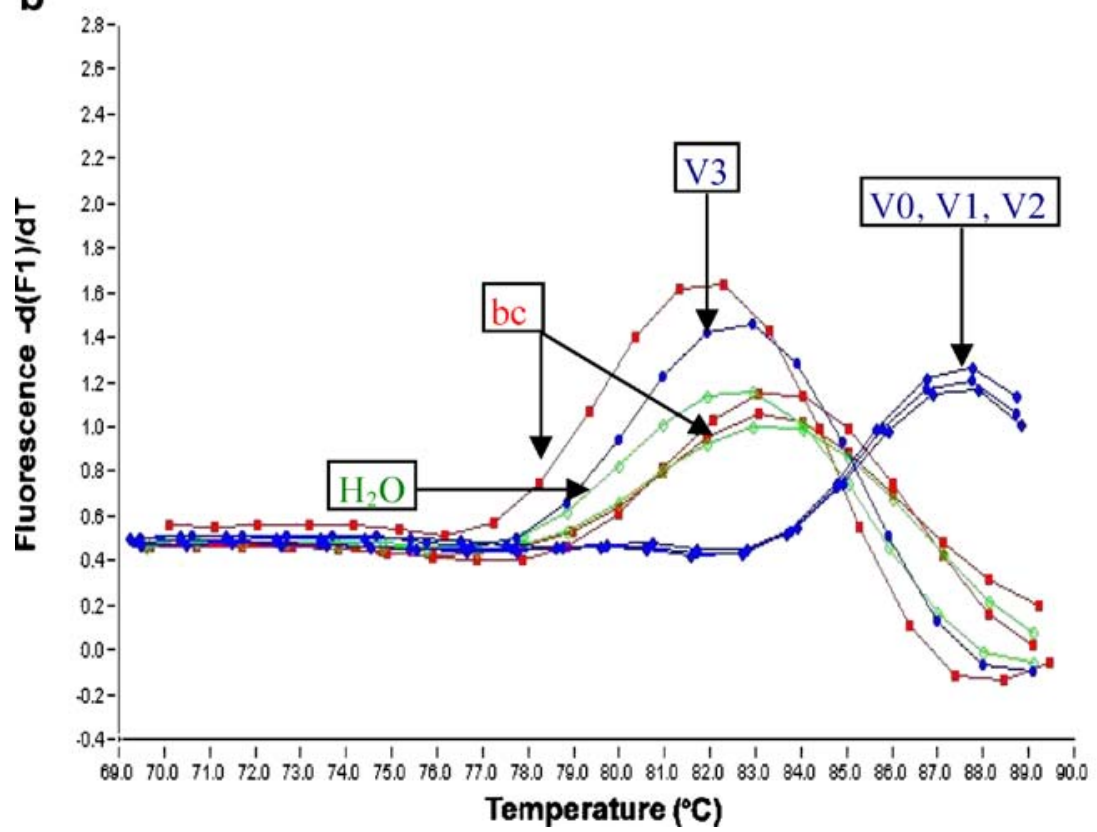

detection. The nested RQ-PCR used a first-round consensus touchdown PCR (starting at $66^{\circ} \mathrm{C}$ ) with a decreasing annealing temperature profile $\left(-0.5^{\circ} \mathrm{C}\right.$ per cycle) over 28 cycles and 12 additional cycles at $52^{\circ} \mathrm{C}$, followed by the second-round RQ-PCR with a patientspecific ASO primer and an inner consensus primer. Tenfold serial dilutions of the diagnostic leukemic DNA sample were made in normal mononuclear cell DNA (pooled DNAs of six healthy donors) and used for RQPCR amplification in duplicate to generate a standard curve and to determine the sensitivity of the clonespecific Ig/TCR target. After receiving the follow-up samples, a freshly prepared dilution series was used to quantify the tumor load in triplicate in the patient's remission samples.

Since the assays for MRD detection in plasma were performed at very low concentrations of DNA (about $1 \mathrm{ng}$ DNA per PCR), we were not able to perform quantitative measurements and defined positivity or negativity on the basis of melting curve analysis. Each sample was analyzed in duplicate and the results for the sample assessed qualitatively and reported as double negative, single, or double positive. Thus, the specificity of MRD assays on plasma DNA was based on the combination of allelespecific oligonucleotides (ASO) and target-specific melting curve analysis. 


\section{Results}

\section{Median plasma DNA concentration}

The concentration of total free plasma DNA was determined in three sets of samples (I, II, and III). Set I included 150 PB plasma samples from 21 children with ALL at diagnosis and under treatment; Set II included 20 PB plasma samples from 13 children with other malignancies receiving treatment and Set III were 12 PB plasma samples from 12 healthy children (Table 1). The results revealed a wide spectrum of DNA concentrations, ranging from 2.85 to $12,260 \mathrm{ng} / \mathrm{ml}$. Interestingly, the median concentrations between the three groups were highly comparable (I: $71 \mathrm{ng} / \mathrm{ml}$, II: $76 \mathrm{ng} / \mathrm{ml}$, and III: $57 \mathrm{ng} / \mathrm{ml})$. When the ALL group was analyzed according to treatment day, it became apparent that initially, plasma DNA was elevated and upon treatment initiation rapidly returned to normal levels
(Fig. 2a). Plasma DNA concentrations on days 0 and 3 were significantly higher in comparison to levels thereafter ( $P$ Mann-Whitney Test=0.001). This decrease paralleled the decline in PB leukocyte numbers (Fig. 2b) and we observed a previously unreported correlation between the concentration of plasma DNA from children with ALL and the number of PB leukocytes (Spearman coefficient of correlation $=0.21, P=.001$; data not shown). Two smaller peaks in DNA concentration were observed on day 33 and week 12.

\section{Detection of MRD}

MRD measurements were performed whenever less than or equal to five serial plasma samples were available which was the case for 15 of the 21 patients with ALL. Characteristics of these 21 patients are shown in Table 2. MRD was consistently detected until day 7 and MRD
Fig. 2 Plasma DNA concentration in children with ALL, other malignancies and healthy controls. a Synopsis of the plasma DNA concentration in group I, patients with childhood ALL at day 0 , day 3 , and $\geq$ day 4 of treatment; group II, patients with other malignancies (non- $A L L$ ); and group III, healthy controls (controls). Each box represents the values between the 1st and 3rd quartile. The bar indicates the median DNA concentration with the absolute value being given next to each box. b The median plasma DNA concentration and median number of leukocytes in children with ALL over the course of therapy, reflecting a correlation between the plasma concentration and the number of leukocytes. For the correlation between median plasma DNA concentration and time points during ALL therapy, we only analyzed time points where greater than or equal to five samples had been collected a

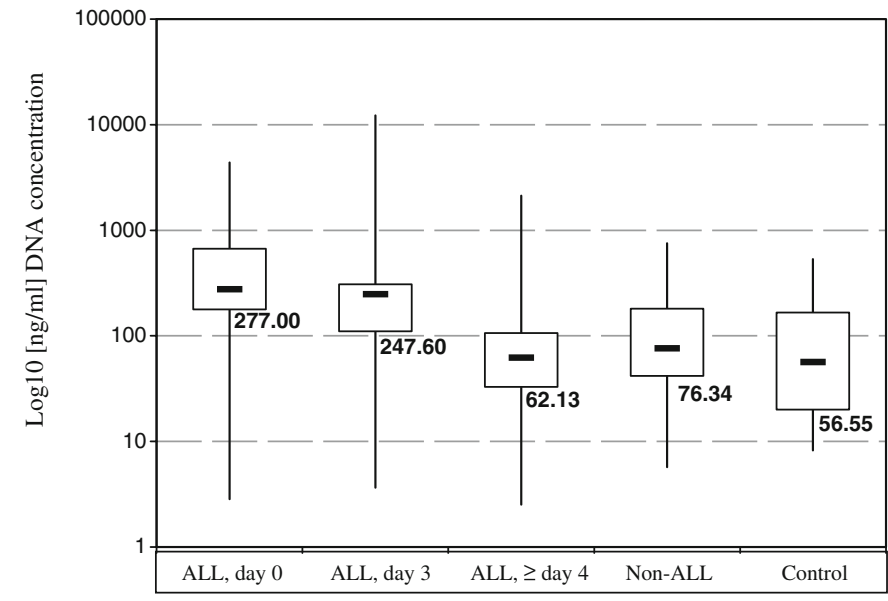

b

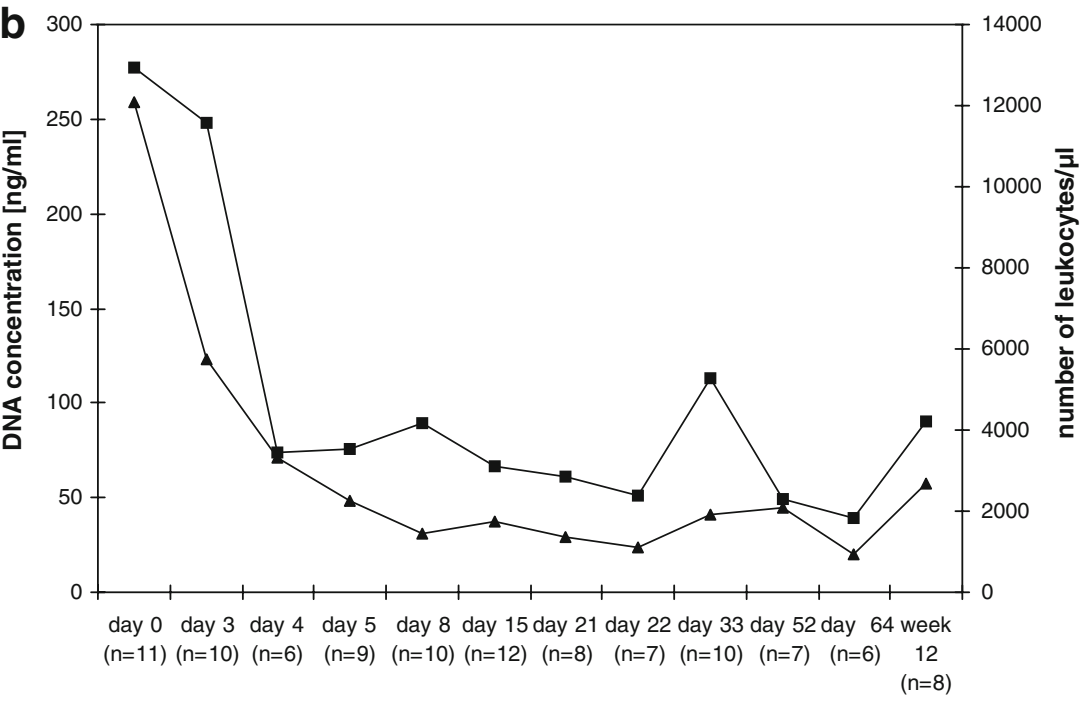

time points

- median DNA concentration ——-median number of leukocytes 
Table 2 Characteristics of patients with acute lymphoblastic leukemia included in the present study and evaluated for plasma DNA (all patients) and plasma DNA MRD monitoring (patients \#7 to \#15)

\begin{tabular}{|c|c|c|c|c|c|c|c|c|c|c|c|}
\hline \multirow[t]{3}{*}{ Patients } & \multirow{3}{*}{$\begin{array}{l}\text { Age at diagnosis } \\
\text { (years) }\end{array}$} & \multirow[t]{3}{*}{ Gender } & \multirow{3}{*}{$\begin{array}{l}\text { WBC at } \\
\text { diagnosis }\end{array}$} & \multirow{3}{*}{$\begin{array}{l}\text { Immuno- } \\
\text { phenotype }\end{array}$} & \multirow{3}{*}{$\begin{array}{l}\text { TEL/ } \\
\text { AML1 }\end{array}$} & \multirow{3}{*}{$\begin{array}{l}\text { Prednisone } \\
\text { response }\end{array}$} & \multirow{3}{*}{$\begin{array}{l}\text { MRD risk } \\
\text { group }\end{array}$} & \multirow{3}{*}{$\begin{array}{l}\text { Number of MRD } \\
\text { markers }\end{array}$} & \multicolumn{2}{|c|}{ MRD } & \multirow[t]{3}{*}{ Relapse } \\
\hline & & & & & & & & & Day & Day & \\
\hline & & & & & & & & & 33 & 78 & \\
\hline
\end{tabular}

\begin{tabular}{|c|c|c|c|c|c|c|c|c|c|c|c|}
\hline \multicolumn{12}{|c|}{ ALL patients } \\
\hline$\# 1$ & 14.9 & $\mathrm{~m}$ & 31,500 & Common & Neg & Good & MR & 4 & $10^{-2}$ & Neg & $\begin{array}{l}\text { Bone } \\
\text { marrow }\end{array}$ \\
\hline$\# 2$ & 15.7 & $\mathrm{~m}$ & 2,500 & Common & $\mathrm{Neg}$ & Good & HR & 2 & $10^{-2}$ & $\begin{array}{l}10^{-2 /} \\
-3\end{array}$ & - \\
\hline$\# 3$ & 4.3 & $\mathrm{f}$ & 3,300 & common & Neg & Good & MR & 2 & $10^{-4}$ & Neg & - \\
\hline$\# 4$ & 4.3 & $\mathrm{f}$ & 15,000 & Pre-B & Pos & Good & No markers & 0 & - & - & - \\
\hline$\# 5$ & 3.2 & $\mathrm{f}$ & 41,000 & Unknown & Neg & Good & SR & 2 & $\mathrm{Neg}$ & Neg & - \\
\hline$\# 6$ & 15.5 & $\mathrm{f}$ & 38,600 & $\mathrm{~T}$ & Neg & Good & No markers & 0 & - & - & - \\
\hline \multicolumn{12}{|c|}{ Patients with MRD monitoring in plasma DNA } \\
\hline$\# 7$ & 12.7 & $\mathrm{f}$ & 5,400 & Common & Neg & Good & HR & 3 & $10^{-3}$ & $10^{-3}$ & - \\
\hline$\# 8$ & 8.6 & $\mathrm{f}$ & 7,100 & $\mathrm{~T}$ & Neg & Good & $\mathrm{HR}$ & 2 & $10^{-2}$ & $10^{-3}$ & - \\
\hline$\# 9$ & 4.6 & $\mathrm{f}$ & 2,800 & Common & Neg & Good & MR & 3 & $10^{-5}$ & $10^{-5}$ & - \\
\hline$\# 10$ & 9.4 & $\mathrm{f}$ & 17,800 & Common & $\mathrm{Neg}$ & Good & SR & 4 & Neg & Neg & - \\
\hline$\# 11$ & 2.6 & $\mathrm{~m}$ & 7,200 & Common & Neg & Good & MR & 2 & $10^{-4}$ & $10^{-4}$ & - \\
\hline$\# 12$ & 18.0 & $\mathrm{~m}$ & 52,800 & Pre-B & Neg & Good & SR & 3 & Neg & Neg & - \\
\hline$\# 13$ & 5.2 & $\mathrm{~m}$ & 76,800 & Common & Pos & Poor & MR & 2 & $10^{-3}$ & $10^{-4}$ & - \\
\hline$\# 14$ & 4.1 & $\mathrm{f}$ & 90,200 & Common & $\mathrm{Neg}$ & Good & MR & 3 & $10^{-3}$ & Neg & $\begin{array}{l}\text { Bone } \\
\text { marrow }\end{array}$ \\
\hline$\# 15$ & 8.3 & $\mathrm{~m}$ & 2,300 & Common & Neg & Good & SR & 3 & Neg & Neg & - \\
\hline$\# 16$ & 7.8 & $\mathrm{~m}$ & 33,600 & Common & Neg & Good & MR & 4 & $10^{-4}$ & Neg & - \\
\hline$\# 17$ & 4.1 & $\mathrm{~m}$ & 18,300 & Common & Pos & Good & SR & 2 & Neg & Neg & - \\
\hline$\# 18$ & 13.4 & $\mathrm{f}$ & 125,000 & Common & Neg & Poor & MR & 3 & $10^{-4}$ & Neg & $\begin{array}{l}\text { Bone } \\
\text { marrow }\end{array}$ \\
\hline$\# 19$ & 5.2 & $\mathrm{f}$ & 5,700 & Common & Neg & Good & SR & 3 & $\mathrm{Neg}$ & Neg & $\begin{array}{l}\text { Bone } \\
\text { marrow }\end{array}$ \\
\hline$\# 20$ & 15.2 & $\mathrm{~F}$ & 3,000 & Common & Neg & Good & MR & 2 & $10^{-4}$ & Neg & - \\
\hline$\# 21$ & 3.4 & $\mathrm{~F}$ & 17,100 & Common & Neg & Good & MR & 2 & $10^{-3}$ & Neg & $\begin{array}{l}\text { Bone } \\
\text { marrow }\end{array}$ \\
\hline
\end{tabular}

$m$ Male, $f$ female, good less than 1,000 leukemic blood blasts on treatment day 8, poor more than 1,000 leukemic blood blasts, $S R$ negative at days 33 and $78, H R$ still $10^{-3}$ or more at day $78, M R$ all others, TEL/AML1 fusion transcript positivity, none of the patients was positive for the BCR/ ABL fusion transcript or an MLL aberration

kinetics could be described for all of the 15 patients. Figure 3a shows a steady decrease in the percentage of plasma MRD-positive patients during early therapy with samples for the majority of patients becoming MRD negative by day 22. All 15 patients were below the detection limits of MRD after day 52. The earliest MRD negative results were observed at day 8 in two out of ten patients tested.

When we compared the MRD measurements in plasma and leukocytes, we discovered a high concordance (86.7\%) between the results. In 32 pairs, MRD was detected in both PB leukocytes and plasma, in eight pairs, MRD was solely detected in PB leukocytes, in two pairs, only the plasma sample was MRD-positive, and in 33 pairs, MRD was negative both in plasma and PB leukocytes. Similar to our observations in plasma analysis, there was a change from predominantly positive MRD signals to predominantly negative findings between day 21 and 22 in the leukocytes.

\section{Discussion}

The present study is the first approach to quantify the concentration of total plasma DNA in healthy children and children with malignant diseases by RQ-PCR. It is widely known that a substantial, if not predominant (depending on the course of therapy) portion of plasma DNA in cancer patients derives from tumor cells [27]. Higher plasma concentrations have been described in patients with large tumors or at an advanced stage of the disease [2, 3, 9, 28, 29 ] and it has been postulated that circulating plasma DNA in these disease states originates largely from tumor lysis/ 
Fig. 3 Detection of MRD in childhood ALL. a Synopsis of MRD in plasma over the course of therapy showing a steady decrease of percentage of MRD. We performed MRD measurements when greater than or equal to five serial plasma samples had been obtained. $\mathbf{b}$ Comparison of MRD in PB plasma vs. MRD in peripheral leukocytes as detected in 75 paired samples indicating a high concordance of $86.7 \%$

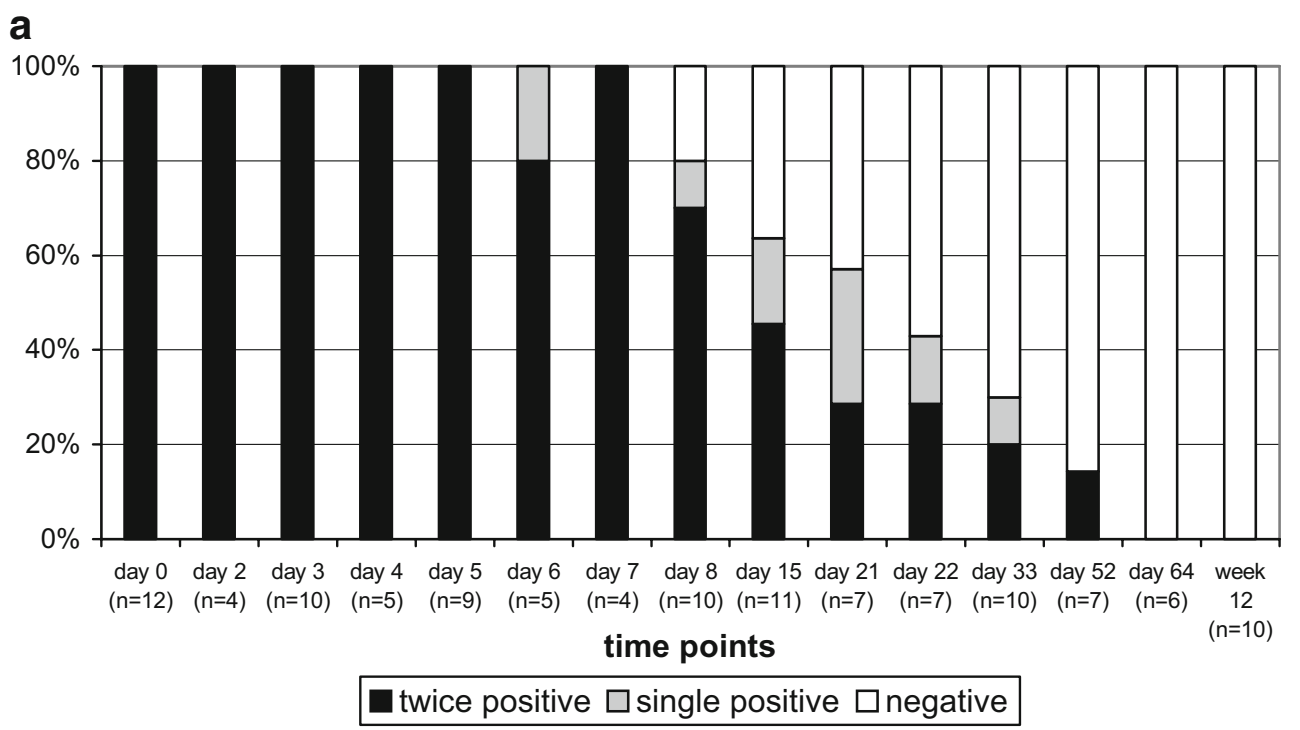

b

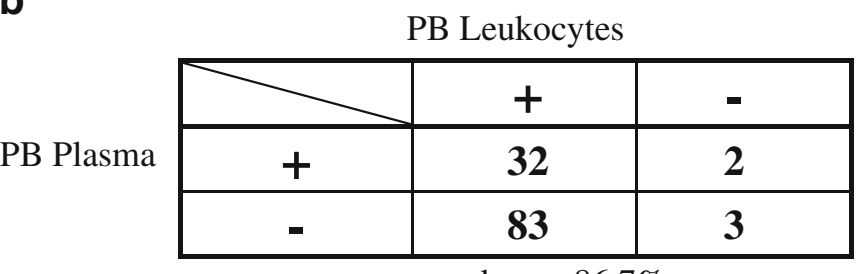

concordance: $86.7 \%$ necrosis and apoptosis. In 2001, Jahr et al. described a significant increase of plasma DNA after induction of apoptosis and necrosis in both, a cell culture and a murine model system, with the increase being more impressive in the necrosis model [30]. Similar findings were reported by Li et al. in 2003 in tumor cell lines and cell tissue cultures [31].

Our results reveal that DNA is abundant at high levels in the plasma of children with ALL at initial diagnosis and decreased rapidly in the first few days after the initiation of therapy to reach a level that is comparable to that of either children with other malignancies or to healthy children. Interestingly, small increases in plasma DNA concentrations were also observed during therapy intermission periods (day 33 and week 12) when active bone marrow regeneration occurs (Fig. 2b).

We were able to demonstrate higher plasma DNA levels in patients newly diagnosed with ALL. Since the amount of total PB plasma DNA in all analyzed patients decreased rapidly and reached levels comparable to those observed in healthy subjects by the fourth treatment day, the method does not seem to be broadly applicable for prognostic purposes in childhood ALL. Thus, we explored instead the applicability of MRD techniques in plasma. For this purpose, we successfully adapted the techniques used for MRD studies in bone marrow for the use with plasma DNA. The observed high initial concentration of both total DNA as well as leukemia-specific DNA in plasma before the induction of chemotherapy was predictable. It can most likely be explained by the higher turnover rate of leukemic cells in comparison to normal cells, which, combined with incomplete processing and degradation of cellular contents would lead to higher abundance of DNA in plasma [15]. In this context, Frickhofen et al. speculated that, normally, there is a steady state between DNA release from cells and degradation by plasma nucleases [14]. On treatment day 3 , after significant tumor lysis, the levels of both total DNA and MRD are still very high in plasma so that we assume that the plasma nucleases are not able to cope with the amount of circulating DNA being released from leukemic cells in these first days. Subsequently, plasma concentrations were restored rapidly which is consistent with the view that the interference with DNA replication may shift the balance towards degradation of DNA. It is interesting that the rapid decline in number of leukocytes did not lead to a transient increase in the concentration of circulating plasma DNA (Fig. 2b) suggesting mechanisms other than tumor lysis may play a role here. Unfortunately, we can not make any interferences on the plasma DNA levels of the children with other malignancies (group II) at diagnosis as in this group we only had access to plasma samples under treatment.

Nevertheless, the origin of the baseline level of plasma DNA which is also present in normal individuals remains unanswered. One hypothesis is that DNA is spontaneously and actively released from intact cells, given the evidence 
that there are marked differences between released DNA and cellular DNA which suggests that the extracellular DNA is not simply derived from dying cells [27, 32, 33]. This theory is supported by the correlation between the concentration of plasma DNA from children with ALL and the number of leukocytes shown in our study.

In summary, we were able to quantify plasma DNA in children using RQ-PCR and demonstrate that it is feasible to use plasma for the evaluation of DNA-based MRD kinetics during the early course of childhood ALL treatment. However, we were neither able to demonstrate a superior role of plasma DNA-based MRD analysis in comparison to conventional MRD analyses relying on DNA from BM or PB cells nor were we able to prove an added clinical value of this method in association with the already-established MRD techniques $[34,35]$.

Acknowledgments We acknowledge the cooperation of all patients and their parents, nurses, and physicians who contributed to the collection of samples for this study. We thank Nicole Wittner for expert technical assistance and Dr. Martin Zimmermann for statistical tests and discussion. This work was supported by the Deutsche Krebshilfe (Bonn, Germany) and the Leukemia Research Foundation (Chicago, IL, USA).

\section{References}

1. Leon SA, Shapiro B, Sklaroff DM, Yaros MJ (1977) Free DNA in the serum of cancer patients and the effect of therapy. Cancer Res 37:646-650

2. Shapiro B, Chakrabarty M, Cohn EM, Leon SA (1983) Determination of circulating DNA levels in patients with benign or malignant gastrointestinal disease. Cancer 51:2116-2120 doi:10.1002/1097-0142(19830601)51:11<2116::AIDCNCR2820511127>3.0.CO;2-S

3. Stroun M, Anker P, Lyautey J, Lederrey C, Maurice PA (1987) Isolation and characterization of DNA from the plasma of cancer patients. Eur J Cancer Clin Oncol 23:707-712 doi:10.1016/02775379(87)90266-5

4. Anker P, Stroun M (2001) Tumor-related alterations in circulating DNA, potential for diagnosis, prognosis and detection of minimal residual disease. Leukemia 15:289-291 doi:10.1038/sj.leu. 2402016

5. Anker P, Lefort F, Vasioukhin V, Lyautey J, Lederrey C, Chen XQ, Stroun M, Mulcahy HE, Farthing MJ (1997) K-ras mutations are found in DNA extracted from the plasma of patients with colorectal cancer. Gastroenterology 112:1114-1120 doi:10.1016/S0016-5085 (97)70121-5

6. Chen XQ, Stroun M, Magnenat JL, Nicod LP, Kurt AM, Lyautey J, Lederrey C, Anker P (1996) Microsatellite alterations in plasma DNA of small cell lung cancer patients. Nat Med 2:1033-1035 see comments doi:10.1038/nm0996-1033

7. Nawroz H, Koch W, Anker P, Stroun M, Sidransky D (1996) Microsatellite alterations in serum DNA of head and neck cancer patients. Nat Med 2:1035-1037 doi:10.1038/nm0996-1035

8. Goessl C, Heicappell R, Munker R, Anker P, Stroun M, Krause H, Muller M, Miller K (1998) Microsatellite analysis of plasma DNA from patients with clear cell renal carcinoma. Cancer Res 58:4728-4732

9. Fujiwara Y, Chi DD, Wang H, Keleman P, Morton DL, Turner R, Hoon DS (1999) Plasma DNA microsatellites as tumor-specific markers and indicators of tumor progression in melanoma patients. Cancer Res 59:1567-1571

10. Esteller M, Sanchez-Cespedes M, Rosell R, Sidransky D, Baylin SB, Herman JG (1999) Detection of aberrant promoter hypermethylation of tumor suppressor genes in serum DNA from non-small cell lung cancer patients. Cancer Res 59:67-70

11. Wong IH, Lo YM, Zhang J, Liew CT, Ng MH, Wong N, Lai PB, Lau WY, Hjelm NM, Johnson PJ (1999) Detection of aberrant p16 methylation in the plasma and serum of liver cancer patients. Cancer Res 59:71-73

12. Silva JM, Dominguez G, Villanueva MJ, Gonzalez R, Garcia JM, Corbacho C, Provencio M, Espana P, Bonilla F (1999) Aberrant DNA methylation of the p16INK4a gene in plasma DNA of breast cancer patients. Br J Cancer 80:1262-1264 doi:10.1038/sj. bjc. 6690495

13. Vasioukhin V, Anker P, Maurice P, Lyautey J, Lederrey C, Stroun M (1994) Point mutations of the N-ras gene in the blood plasma DNA of patients with myelodysplastic syndrome or acute myelogenous leukaemia. Br J Haematol 86:774-779 doi:10.1111/j.13652141.1994.tb04828.x

14. Frickhofen N, Muller E, Sandherr M, Binder T, Bangerter M, Wiest C, Enz M, Heimpel H (1997) Rearranged Ig heavy chain DNA is detectable in cell-free blood samples of patients with B-cell neoplasia. Blood 90:4953-4960

15. Rogers A, Joe Y, Manshouri T, Dey A, Jilani I, Giles F, Estey E, Freireich E, Keating M, Kantarjian H, Albitar M (2004) Relative increase in leukemia-specific DNA in peripheral blood plasma from patients with acute myeloid leukemia and myelodysplasia. Blood 103:2799-2801 doi:10.1182/blood-2003-06-1840

16. Stanulla M, Schrappe M (2009) Treatment of childhood acute lymphoblastic leukemia. Semin Hematol 46:52-63 doi:10.1053/j. seminhematol.2008.09.007

17. Cario G, Stanulla M, Fine BM, Teuffel O, Neuhoff NV, Schrauder A, Flohr T, Schafer BW, Bartram CR, Welte K, Schlegelberger B, Schrappe M (2005) Distinct gene expression profiles determine molecular treatment response in childhood acute lymphoblastic leukemia. Blood 105:821-826 doi:10.1182/blood-2004-04-1552

18. Cave H, van der Werff ten Bosch J, Suciu S, Guidal C, Waterkeyn C, Otten J, Bakkus M, Thielemans K, Grandchamp B, Vilmer E (1998) Clinical significance of minimal residual disease in childhood acute lymphoblastic leukemia. European Organization for Research and Treatment of Cancer-Childhood Leukemia Cooperative Group. N Eng1 J Med 339:591-598 see comments doi:10.1056/ NEJM199808273390904

19. van Dongen JJM, Seriu T, Panzer-Grumayer ER, Biondi A, Pongers-Willemse MJ, Corral L, Stolz F, Schrappe M, Masera G, Kamps WA, Gadner H, van Wering ER, Ludwig W-D, Basso G, de Bruijn MAC, Cazzaniga G, Hettinger K, van der Does-van den Berg A, Hop WCJ, Riehm H, Bartram CR (1998) Prognostic value of minimal residual disease in childhood acute lymphoblastic leukemia: a prospective study of the International BFM Study Group. Lancet 352:1731-1738 doi:10.1016/S0140-6736(98) 04058-6

20. Flohr T, Schrauder A, Cazzaniga G, Panzer-Grumayer R, van der Velden V, Fischer S, Stanulla M, Basso G, Niggli FK, Schafer BW, Sutton R, Koehler R, Zimmermann M, Valsecchi MG, Gadner H, Masera G, Schrappe M, van Dongen JJ, Biondi A, Bartram CR (2008) Minimal residual disease-directed risk stratification using real-time quantitative PCR analysis of immunoglobulin and T-cell receptor gene rearrangements in the international multicenter trial AIEOP- 
BFM ALL 2000 for childhood acute lymphoblastic leukemia. Leukemia 31:31

21. Lee TH, Montalvo L, Chrebtow V, Busch MP (2001) Quantitation of genomic DNA in plasma and serum samples: higher concentrations of genomic DNA found in serum than in plasma. Transfusion 41:276-282 doi:10.1046/j.1537-2995.2001.41020276.x

22. Anker P, Stroun M, Maurice PA (1975) Spontaneous release of DNA by human blood lymphoctyes as shown in an in vitro system. Cancer Res 35:2375-2382

23. Nakao M, Janssen JW, Flohr T, Bartram CR (2000) Rapid and reliable quantification of minimal residual disease in acute lymphoblastic leukemia using rearranged immunoglobulin and T-cell receptor loci by LightCycler technology. Cancer Res 60:3281-3289

24. van der Velden VH, Hochhaus A, Cazzaniga G, Szczepanski T, Gabert J, van Dongen JJ (2003) Detection of minimal residual disease in hematologic malignancies by real-time quantitative PCR: principles, approaches, and laboratory aspects. Leukemia 17:1013-1034 doi:10.1038/sj.leu.2402922

25. van der Velden VH, Cazzaniga G, Schrauder A, Hancock J, Bader P, Panzer-Grumayer ER, Flohr T, Sutton R, Cave H, Madsen HO, Cayuela JM, Trka J, Eckert C, Foroni L, Zur Stadt U, Beldjord K, Raff T, van der Schoot CE, van Dongen JJ (2007) Analysis of minimal residual disease by $\mathrm{Ig} / \mathrm{TCR}$ gene rearrangements: guidelines for interpretation of real-time quantitative PCR data. Leukemia 21:604-611

26. van der Velden VH, Panzer-Grumayer ER, Cazzaniga G, Flohr T, Sutton R, Schrauder A, Basso G, Schrappe M, Wijkhuijs JM, Konrad M, Bartram CR, Masera G, Biondi A, van Dongen JJ (2007) Optimization of PCR-based minimal residual disease diagnostics for childhood acute lymphoblastic leukemia in a multi-center setting. Leukemia 21:706-713

27. Stroun M, Maurice P, Vasioukhin V, Lyautey J, Lederrey C, Lefort F, Rossier A, Chen XQ, Anker P (2000) The origin and mechanism of circulating DNA. Ann N Y Acad Sci 906:161-168
28. Stroun M, Anker P, Maurice P, Lyautey J, Lederrey C, Beljanski M (1989) Neoplastic characteristics of the DNA found in the plasma of cancer patients. Oncology 46:318-322

29. Fournie GJ, Courtin JP, Laval F, Chale JJ, Pourrat JP, Pujazon MC, Lauque D, Carles P (1995) Plasma DNA as a marker of cancerous cell death. Investigations in patients suffering from lung cancer and in nude mice bearing human tumours. Cancer Lett 91:221-227 doi:10.1016/0304-3835(95)03742-F

30. Jahr S, Hentze H, Englisch S, Hardt D, Fackelmayer FO, Hesch RD, Knippers R (2001) DNA fragments in the blood plasma of cancer patients: quantitations and evidence for their origin from apoptotic and necrotic cells. Cancer Res 61:1659-1665

31. Li CN, Hsu HL, Wu TL, Tsao KC, Sun CF, Wu JT (2003) Cellfree DNA is released from tumor cells upon cell death: a study of tissue cultures of tumor cell lines. J Clin Lab Anal 17:103-107 doi:10.1002/jcla.10081

32. Jachertz D, Anker P, Maurice PA, Stroun M (1979) Information carried by the DNA released by antigen-stimulated lymphocytes. Immunology 37:753-763

33. Stroun M, Lyautey J, Lederrey C, Mulcahy HE, Anker P (2001) Alu repeat sequences are present in increased proportions compared to a unique gene in plasma/serum DNA: evidence for a preferential release from viable cells? Ann N Y Acad Sci 945:258-264

34. Coustan-Smith E, Sancho J, Hancock ML, Razzouk BI, Ribeiro RC, Rivera GK, Rubnitz JE, Sandlund JT, Pui CH, Campana D (2002) Use of peripheral blood instead of bone marrow to monitor residual disease in children with acute lymphoblastic leukemia. Blood 100:2399-2402 doi:10.1182/blood-2002-04-1130

35. van der Velden VH, Jacobs DC, Wijkhuijs AJ, Comans-Bitter WM, Willemse MJ, Hahlen K, Kamps WA, van Wering ER, van Dongen JJ (2002) Minimal residual disease levels in bone marrow and peripheral blood are comparable in children with $\mathrm{T}$ cell acute lymphoblastic leukemia (ALL), but not in precursor-B-ALL. Leukemia 16:14321436 doi: $10.1038 /$ sj.leu.2402636 